\title{
A Research on Groundwater Fluctuation due to Rainfall in Chidambaram Taluk of Cuddalore District, Tamilnadu
}

\author{
N. Nagarajan, P. Sivarajan, K. Karthikeyan, S. Sivaprakasam
}

\begin{abstract}
Water plays an important role in development of economy of a country and agricultural activities in all parts of the world. Ground water depends upon hydrology, land use, soil, geology, geomorphology and aquifer characteristics of the study area. An important component of water balance equation is ground water recharge. This study focuses mainly on the causes of groundwater fluctuation and its trend as well as to determine the amount of recharge in the study area by rainfall infiltration. The fluctuations of ground water level, variation of monthly rainfall, were analyzed in the study area. The vertical change in storage is not same throughout the year due to variation in rainfall and infiltration rate of soil. The maximum and minimum depths of water table were found respectively. Monthly variation of rainfall follows the usual pattern of monsoon with heavy rain from November to December. The maximum infiltration as well as runoff also occurred from November and December due to maximum rainfall and the infiltration, runoff is negligible during the rest of the year due to very meager rainfall.
\end{abstract}

Keywords: groundwater fluctuation, hydrologic parameter, infiltration, rainfall-runoff.

\section{INTRODUCTION}

Groundwater recharge is a hydrologic process wherein water moves downward from surface to beneath the ground. It is an important process for sustainable groundwater management, since the volume-rate abstracted from an aquifer in the long term should be less than or equal to the volume-rate that is recharged. Recharge of groundwater is affected both naturally (through the water cycle) and anthropogenically (i.e., "artificial groundwater recharge"), where rainwater or reclaimed water is routed to the subsurface. Recharge may be impeded somewhat by human activities including paving, development or logging. These activities can result in enhanced surface runoff and reduce infiltration. The use of groudwater, especially for irrigation, industrialization and domestic water supply may lower the water table. Hence, the stress on water resources owing to flying population, disorganized industrialization and hasty

Revised Version Manuscript Received on August 19, 2019.

Dr. N. Nagarajan, Associate Professor, Department of Civil Engineering, Faculty of Engineering and Technology,Annamalai University, Annamalai Nagar, Tamilnadu, India. (email: nnrajan.au@gmail.com)

Dr. P. Sivarajan, Associate Professor, Department of Civil Engineering, Faculty of Engineering and Technology,Annamalai University, Annamalai Nagar, Tamilnadu, India.

Dr. K. Karthikeyan, Associate Professor, Department of Civil Engineering, Faculty of Engineering and Technology,Annamalai University, Annamalai Nagar, Tamilnadu, India.

Dr. S. Sivaprakasam, Associate Professor, Department of Civil Engineering, Faculty of Engineering and Technology, Annamalai University, Annamalai Nagar, Tamilnadu, India. urbanization, leads to various problems in coastal regions such as worsening of water quality and menace to the sustainability of groundwater resources. Therefore, monitoring groundwater levels and to analyze the trend of groundwater fluctuation in a region is of utmost importance. This study pacts the groundwater fluctuation due to annual and seasonal variation in rainfall.

The specific objectives of the present study are,

* To analysis the seasonal and annual rainfall pattern in the study area.

* To analysis the groundwater level fluctuation and its trend

\section{STUDY AREA}

Cuddalore district lies between $11^{\circ} 09^{\prime} \mathrm{N}-11^{\circ} 53^{\prime} \mathrm{N}$ and $78^{\circ} 52^{\prime} \mathrm{E}-79^{\circ} 51^{\prime} \mathrm{E}$. The district is bounded by Salem district in the West, Villupuram district in the North, Bay of Bengal in the East and Nagapattinam and Perambalur district in the South. The total geographical area of the district is 3486 sq.km. Further, the district has been bifurcated into 6 taluks and 13 blocks as shown in Figure 1. The geographical extent of taluks and blocks of Cuddalore district is presented Table 1 .

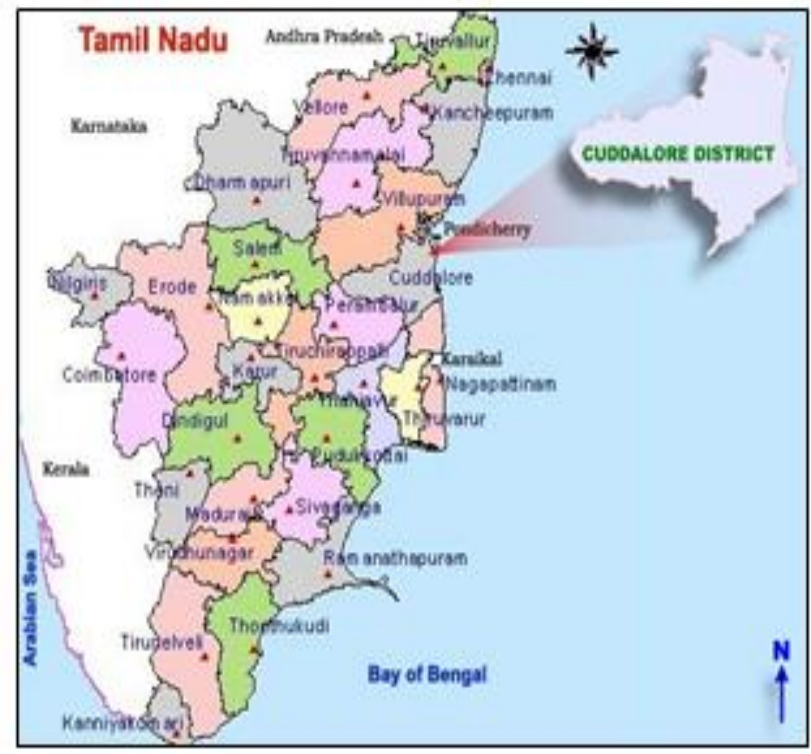

Published By:

Blue Eyes Intelligence Engineering 


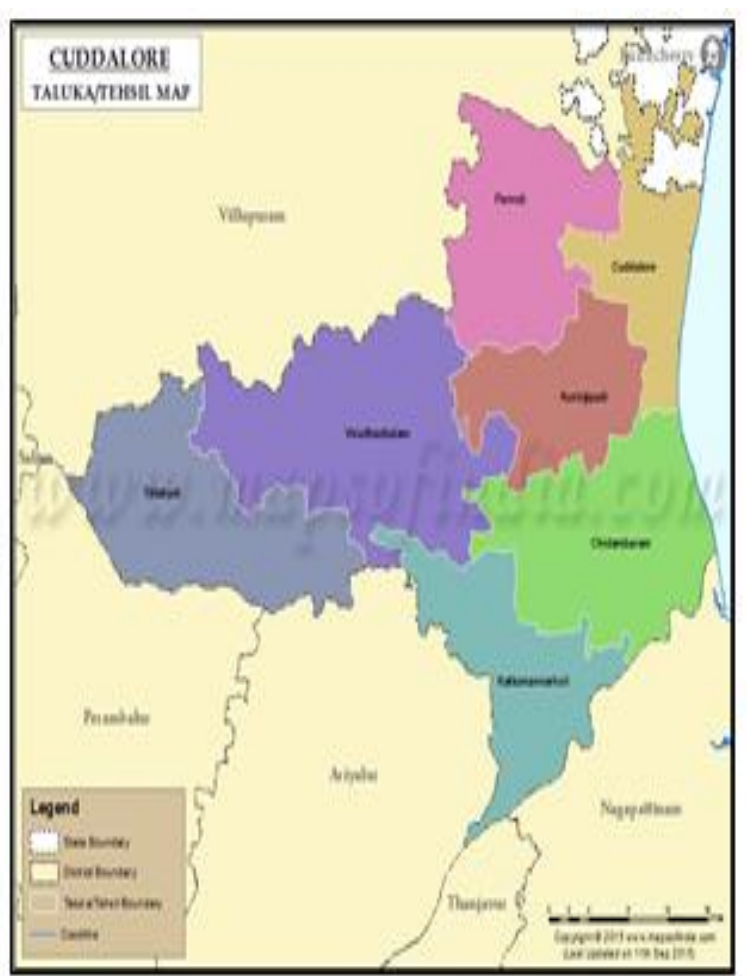

Figure 1 Index map of the study area

Table 1 Taluk-wise geographical area in the study area

\begin{tabular}{|c|c|c|c|c|}
\hline $\begin{array}{l}\text { S. } \\
\text { No. }\end{array}$ & Taluk & $\begin{array}{c}\text { Area in } \\
\text { Hectares }\end{array}$ & Block & $\begin{array}{c}\text { No. of } \\
\text { Village } \\
\text { s }\end{array}$ \\
\hline \multirow{2}{*}{1} & \multirow[b]{2}{*}{ Cuddalore } & \multirow[b]{2}{*}{56645} & Cuddalore & 77 \\
\hline & & & Kurinjipadi & 71 \\
\hline \multirow{2}{*}{2} & \multirow{2}{*}{ Panruti } & \multirow{2}{*}{56097} & Annagramam & 55 \\
\hline & & & Panruti & 44 \\
\hline \multirow{3}{*}{3} & \multirow{3}{*}{ Chidambaram } & \multirow{3}{*}{64582} & Bhuvanagiri & 55 \\
\hline & & & Parangipettai & 57 \\
\hline & & & Keerapalayam & 77 \\
\hline \multirow{2}{*}{4} & \multirow{2}{*}{$\begin{array}{l}\text { Kattumanarko } \\
\text { il }\end{array}$} & \multirow{2}{*}{48523} & Kattumanarkoil & 76 \\
\hline & & & Kumaratchi & 89 \\
\hline \multirow{2}{*}{5} & \multirow{2}{*}{$\begin{array}{l}\text { Vriddhachala } \\
\text { m }\end{array}$} & \multirow{2}{*}{82247} & Vriddhachalam & 69 \\
\hline & & & Kammapuram & 66 \\
\hline \multirow{2}{*}{6} & \multirow{2}{*}{ Thittagudi } & \multirow{2}{*}{59687} & Nallur & 77 \\
\hline & & & Mangalur & 85 \\
\hline
\end{tabular}

\section{A. Physiography}

Being a coastal zone, Cuddalore district is mostly a plain terrain, without any high relief except with some sedimentary high ground in Virudhachalam, Cuddalore and Panruti blocks. The entire district is gently sloping towards eastern coastal region.

\section{B. Geology}

Cuddalore district is broadly classified into hard rock and sedimentary formations. The western part of the district is covered by Granite gneiss, Hornblende gneiss and of Charnockite. Nearly $80 \%$ of the area is covered by sedimentary formation of territory and recent alluvial deposits.

\section{Geomorphology}

The entire districts can be broadly divided into three zones such as, Western Pedi plains covered by denudation landforms like shallow and deep buried pediments, forming the part of Mangalore and Nallur blocks, central sedimentary high ground Cuddalore sandstone of tertiary age covering parts of Virudhachalam, Kammapuram, Kurinjipadi, Cuddalore and Katumannarkoil taluks and eastern coastal plain, which is predominantly occupied by flood plains under the influence of Pennaiyar, Vellar and Coleroon Rivers.

\section{Soil}

The soil classification of the study area is categorized as, red soil, red loamy soil, black soil, sandy soil, alluvial soil and sandy loamy soil.

\section{E. Climate}

Tropical type of climate prevails over the study area with slight variation. The monthly mean maximum temperature in the region ranges within $30.16^{\circ} \mathrm{C}$ to $40.34^{\circ} \mathrm{C}$ and the mean minimum temperature ranges from $20.37^{\circ} \mathrm{C}$ to $26.68^{\circ} \mathrm{C}$.

\section{F. Rainfall}

The average annual rainfall of the study area is 1160.12 $\mathrm{mm}$. Part of the precipitation is from southwest monsoon and most of the rainfall occurs during the northeast monsoon season. Convective precipitation is also experienced during the hot weather season. However, low intensity frontal-type cyclonic rains are also experienced, usually in the winter season. There are 22 rain gauge stations installed in the study area.

\section{G. Drainage}

The entire study area is drained by Gadilam and Pennaiyar rivers in the North, Vellar and Coleroon in the south. These rivers are ephemeral and carry floods during monsoon. They generally flow from west towards east and the pattern is mainly sub parallel. Vellar is a seasonal river, which drains the major portion in the southern part of the district. Manimuktha, Gomukhi and Mayura are the major tributaries which join the Vellar river. The eastern coastal part near Porto-Novo is characterized by lagoons and back waters.

\section{H. Land use}

The land use pattern is categorized as agricultural lands, water bodies, wastelands, settlements, forestlands, etc,

\section{III.METHODOLOGY}

The variations in the monthly rainfall in the study area for the period 1990 to 2008 were obtained and the trends in ground water level for the same period were monitored. Based on these data the variations in groundwater fluctuations were analyzed.

\section{RESULTS AND DISCUSSION}

\section{Variability of rainfall}

The variations of monthly rainfall recorded from rain gauge stations located in the study area during the study period are shown in Figure 2 (a) - (c). The maximum rainfall was recorded during November and December throughout the study period except in the year 2008 and minimum rainfall was found between February and April and very little 

study area. The study also illustrates that during November 2005 maximum rainfall was recorded in the study area leading to flooding. The rainfall data of the study also show a wide variation of rainfall depending on area and year. Planning and management of water harvesting in the study area, due to the limited amount of rainfall than to the inherent degree of variability associated with it and for a water harvesting planner, the most difficult task is therefore to select the appropriate "design" rainfall according to which the ratio of catchment to cultivated area will be determined.

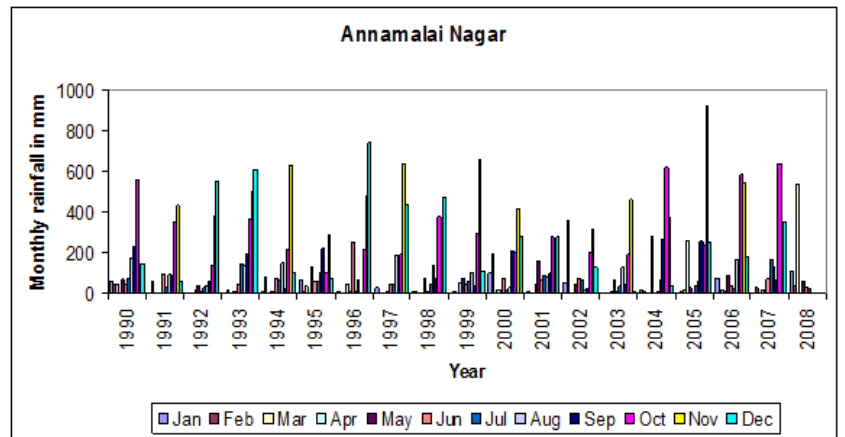

(a)

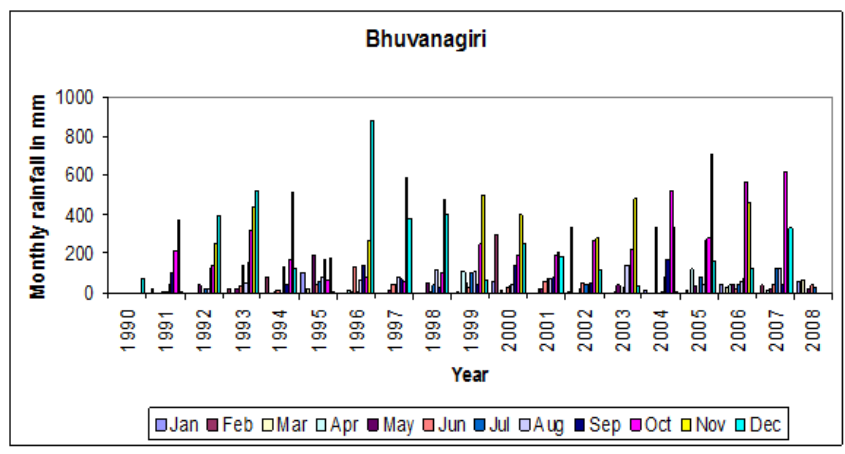

(b)

(c)

Figure 2 (a) - (c) Monthly Rainfall of Annamlainagar, Bhuvanagiri and Chidambaram (1990 - 2008)

Variations in groundwater level

The figure 3 (a) and 3 (b) shows the water level fluctuations in the study area during the study period. The results illustrate that the overall water table level showed minimum in 2008-2009 and maximum in 2005-2006. An elevated water level is seen in 2006 due to higher amount of rainfall received in the study area. The graphs show wave like fluctuation curves, where the highest depletion occurred during May-July and slowly decreased until rain started in or no rainfall occurred during July and September in the

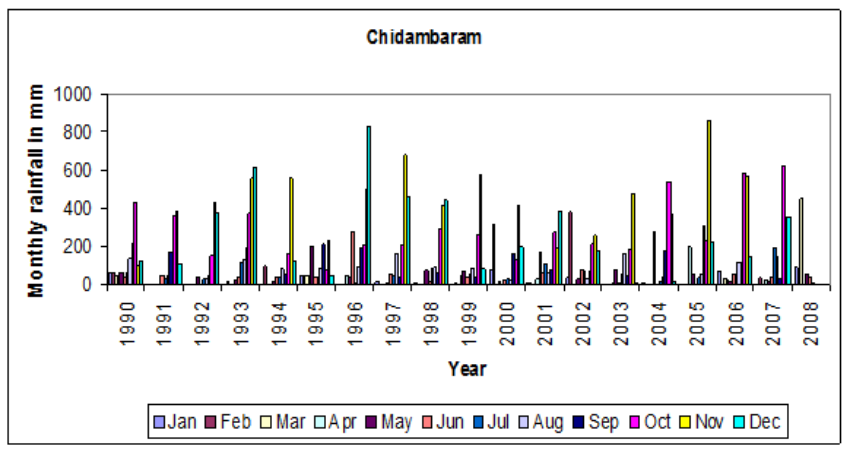

November. Table 2 shows the sample well locations in the study area.

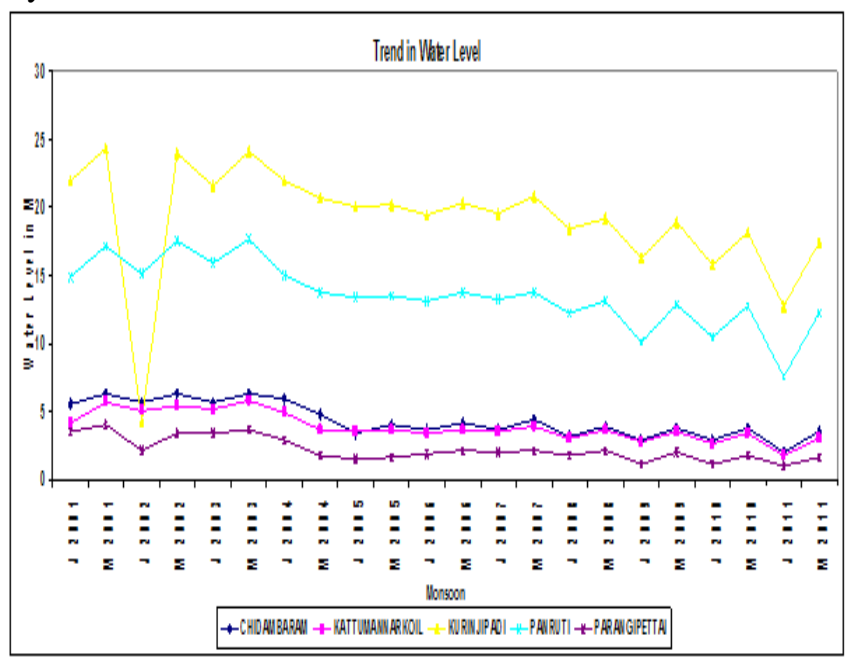

(a)

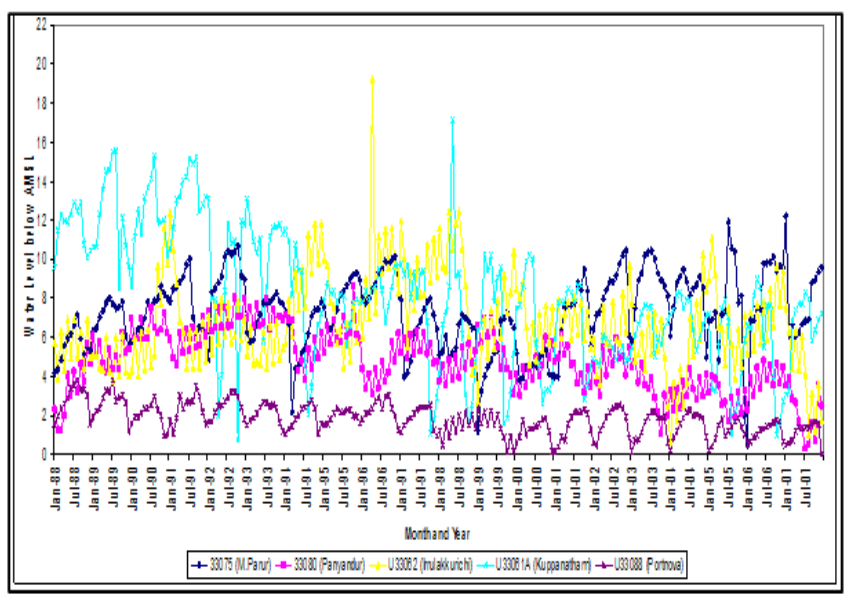

(b)

Figure 3 (a) - (b) Ground Water Level in the study area (Sample Well Locations)

Table 2 Sample Well Locations in the study area

\begin{tabular}{|c|c|c|c|c|}
\hline Well No & $\begin{array}{c}\text { Topo } \\
\text { sheet } \\
\text { No. }\end{array}$ & Latitude & Longitude & $\begin{array}{c}\text { Elevation of } \\
\text { Ground } \\
\text { Level (m) }\end{array}$ \\
\hline 33075 & $\begin{array}{c}58 \\
\text { M/06 }\end{array}$ & $11^{\circ} 34^{\prime} 37^{\prime \prime}$ & $79^{\circ} 15^{\prime} 25^{\prime \prime}$ & 50.54 \\
\hline 33080 & $58 \mathrm{I} / 14$ & $11^{\circ} 30^{\prime} 58^{\prime \prime}$ & $79^{\circ} 55^{\prime} 31^{\prime \prime}$ & 115.19 \\
\hline U33062 & $\begin{array}{c}58 \\
M / 06\end{array}$ & $11^{\circ} 38^{\prime} 30^{\prime \prime}$ & $7^{\circ} 23^{\prime} 00^{\prime \prime}$ & 82.68 \\
\hline U33061A & $\begin{array}{c}\mathbf{5 8} \\
\mathbf{M} / \mathbf{0 6}\end{array}$ & $11^{\circ} 32^{\prime} 45^{\prime \prime}$ & $79^{\circ} 21^{\prime} 10^{\prime \prime}$ & 43.79 \\
\hline U33088 & $58 \mathrm{M} / 5$ & $11^{\circ} 29^{\prime} 20^{\prime \prime}$ & $79^{\circ} 45^{\prime} 30^{\prime \prime}$ & 2.10 \\
\hline
\end{tabular}

\section{Analysis of groundwater level fluctuation}

Groundwater level trend, may be the water table of observation well. Figure 4 (a) and (b) shows the water level fluctuation and the annual rainfall in the study area during the study period. The study results reveal that a good relation 

CUDDALORE DISTRICT, TAMILNADU

between rainfall and water table fluctuations was observed where the groundwater table was recharged by the rainfall. The variation in groundwater table in any area in a year considering the maximum and minimum level is said to be fluctuation of the ground water table. Fluctuation of groundwater level is different in magnitude depending on the extraction and recharge for different location. Based on the available data for the study period, analyzed and found that the water level varies from $1.00 \mathrm{~m}$ to $24.28 \mathrm{~m}$.

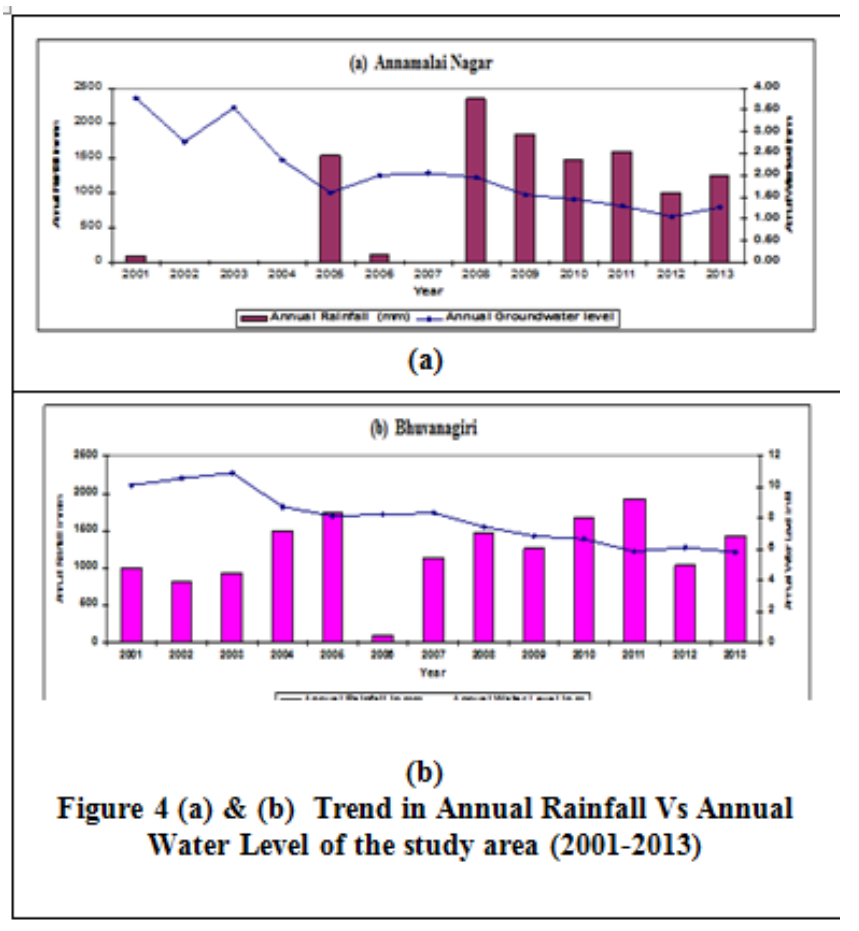

\section{CONCLUSION}

The ground water level in the study area rises and falls continuously with the advance of wet and dry season peak value in month of January and May. Based on the analysis of data the groundwater level varies from $24.28 \mathrm{~m}$ maximum and $1.00 \mathrm{~m}$ minimum.

The characteristic of soil is not favorable to infiltration in the study area. The soil of the study area is clay type which affects infiltration. Therefore, a little amount of rainfall is infiltrated and the change of ground water storage is large. If the present rate of groundwater withdrawal is continued, there is a great possibility of land subsiding formations which may also increases the flood hazard of already low areas.

\section{REFERENCES}

1. Jaya Rami Reddy. P (1997), "Stochastic hydrology", Lakshmi Publications (P) Ltd, New Delhi.

2. Kottegoda. N.T. and M.A. Horder (Dept. of Civil Engg). (1978), "Daily flow model based on rainfall occurrences using pulse and a transfer function", Journal FIN diology, Vol. 47, Pp. 215 - 234.

3. Michael Porch and Ehud Mechrez (1984), "The combined effect of wind and topography on rainfall distribution", Hydrology Journal, Volume 72 (1984), Pp. 1 - 23.

4. Pearce AJ., Gash. J.H.C. and Steward. J.B. (1980), "Rainfall interception in forest estimated from grass land meterological data", Journal Hydrology, Vol. 46: Pp. $147-163$

5. Raghunath H.M. (1985), Stochastic Hydrology, Wiley Eastern Limited, New Delhi.
6. Engineering Hydrology, K. Subramanya, Tata Mc Grow Hill publishing company limited, New Delhi, 2005.

7. Ground water hydrology, David Keith Todd (University of California, Berkeley) and David Keith Todd (consulting Engineer INC, John Wiley \& Sons, 2004)

8. Ground Water Science, Cherles R. Fitts, Academic Press, 2006.

9. Hydrology, H.M. Raghunath, Wiley Eastern Limited, 1986.

10. Elementary Hydrology, Vijay P. Singh, Prentice Hall of India Pvt. Ltd, 1994 